\title{
Students e-Learning Access in Select Higher Learning Institutions of Less-Economically Developed South East Asian Nations: Implications for Economics of Education
}

\author{
JOEL ALANYA-BELTRAN ${ }^{1}$, ZAITUNA KHAMIDULLINA ${ }^{2}$, MOHAMMAD YOUSEF ALSARAIREH ${ }^{3}$, \\ RUSSELL DE SOUZA ${ }^{4}$, VAHDET TARAKCI ${ }^{5}$, JEIDY PANDURO-RAMIREZ ${ }^{6}$, NGUYEN TAN HUNG ${ }^{7}$, \\ SUPAT CHUPRADIT ${ }^{8}$, MYLA M. ARCINAS ${ }^{9}$, HOYAN HANG FUNG, CAROLE $^{10}$ \\ ${ }^{1}$ UNIVERSIDAD TECNOLÓGICA DEL PERÚ, PERÚ, E-mail: c18121@utp.edu.pe \\ ${ }^{2}$ ASTANA MEDICAL UNIVERSITY KAZAKHSTAN, KAZAKHSTAN \\ ${ }^{3}$ AL-BALQA APPLIED UNIVERSITY, JORDAN, E-mail: moh.sarayreh@bau.edu.jo \\ ${ }^{4}$ NIRMALA INSTITUTE OF EDUCATION, Goa, INDIA. E-mail: russsouza@gmail.com \\ ${ }^{5} \mathrm{KHOJA}$ AKHMET YASSAWI INTERNATIONAL KAZAKH-TURSKISH UNIVERSITY, KAZAKHSTAN \\ ${ }^{6}$ UNIVERSIDAD TECNOLÓGICA DEL PERÚ, PERÚ, E-mail: c21289@utp.edu.pe \\ ${ }^{7}$ NATIONAL TAIPEI UNIVERSITY OF TECHNOLOGY, TAIWAN, E-mail: tanhung.mba@gmail.com \\ ${ }^{8}$ CHIANG MAI UNIVERSITY, Chiang Mai, 50200, THAILAND, E-mail: supat.c@cmu.ac.th \\ ${ }^{9}$ DE LA SALLE UNIVERSITY, PHILIPPINES \\ ${ }^{10}$ THE CHINESE UNIVERSITY OF HONG KONG, HONG KONG, E-mail: hoyan@cuhk.edu.hk
}

\begin{abstract}
Because of the growing pandemic of Corona Virus Disease-2019, Higher Education Institutions (HEls) must utilize electronic learning (e-learning). Today's work economy, which is forever in flux because of the creation of new jobs and the continual disappearance of old ones, necessitates an on-the-job shift. Despite HEls in less-wealthy nations like some countries of Asia being developed countries, in essence, it is much more difficult for students and teachers at these higher learning institutions to deal with the transition to e-learning due to their tight financial restrictions. This study sought to determine whether learners at the start of the COVID-19 Era were ready for e-learning and a connection between demographic variables and readiness for e-learning. A quantitative survey obtained information from 1200 students from elite higher educational institutions in South East Asia. A majority of respondents' scores lacked on the Online Learner Readiness Self-Assessment (OLRS). Inadequate OLRS findings among younger, female, and rural respondents. Factors affecting the success of students on the OLRS were age, sex, family socioeconomic status, and where they lived in the neighborhood. The inferences drawn from the study's findings would serve as an excellent benchmark to improve the delivery of elearning processes.
\end{abstract}

Keywords: Economics of education; COVID 19; HEls; Online Learning Readiness; E-learning.

JEL Classification: A20, A29, 120

Received: June 15, 2021

Accepted: September 27, 2021 


\title{
Acceso de los Estudiantes al Aprendizaje Electrónico en determinadas Instituciones de Enseñanza Superior de los Países del Sudeste Asiático menos Desarrollados Económicamente: Implicaciones para la Economía de la Educación
}

\author{
JOEL ALANYA-BELTRAN ${ }^{1}$, ZAITUNA KHAMIDULLINA ${ }^{2}$, MOHAMMAD YOUSEF ALSARAIREH ${ }^{3}$, \\ RUSSELL DE SOUZA ${ }^{4}$, VAHDET TARAKCI ${ }^{5}$, JEIDY PANDURO-RAMIREZ ${ }^{6}$, NGUYEN TAN HUNG ${ }^{7}$, \\ SUPAT CHUPRADIT ${ }^{8}$, MYLA M. ARCINAS $^{9}$, HOYAN HANG FUNG, CAROLE ${ }^{10}$ \\ ${ }^{1}$ UNIVERSIDAD TECNOLÓGICA DEL PERÚ, PERÚ, E-mail: c18121@utp.edu.pe \\ ${ }^{2}$ ASTANA MEDICAL UNIVERSITY KAZAKHSTAN, KAZAKHSTAN \\ ${ }^{3}$ AL-BALQA APPLIED UNIVERSITY, JORDAN, E-mail: moh.sarayreh@bau.edu.jo \\ ${ }^{4}$ NIRMALA INSTITUTE OF EDUCATION, Goa, INDIA. E-mail: russsouza@gmail.com \\ ${ }^{5}$ KHOJA AKHMET YASSAWI INTERNATIONAL KAZAKH-TURSKISH UNIVERSITY, KAZAKHSTAN \\ 6UNIVERSIDAD TECNOLÓGICA DEL PERÚ, PERÚ, E-mail: c21289@utp.edu.pe \\ ${ }^{7}$ NATIONAL TAIPEI UNIVERSITY OF TECHNOLOGY, TAIWAN, E-mail: tanhung.mba@gmail.com \\ ${ }^{8}$ CHIANG MAI UNIVERSITY, Chiang Mai, 50200, THAILAND, E-mail: supat.c@cmu.ac.th \\ ${ }^{9}$ DE LA SALLE UNIVERSITY, PHILIPPINES \\ ${ }^{10}$ THE CHINESE UNIVERSITY OF HONG KONG, HONG KONG, E-mail: hoyan@cuhk.edu.hk
}

\begin{abstract}
RESUMEN
Because of the growing pandemic of Corona Virus Disease-2019, Higher Education Institutions (HEls) must utilize electronic learning (e-learning). Today's work economy, which is forever in flux because of the creation of new jobs and the continual disappearance of old ones, necessitates an on-the-job shift. Despite HEls in less-wealthy nations like some countries of Asia being developed countries, in essence, it is much more difficult for students and teachers at these higher learning institutions to deal with the transition to e-learning due to their tight financial restrictions. This study sought to determine whether learners at the start of the COVID-19 Era were ready for e-learning and a connection between demographic variables and readiness for e-learning. A quantitative survey obtained information from 1200 students from elite higher educational institutions in South East Asia. A majority of respondents' scores lacked on the Online Learner Readiness Self-Assessment (OLRS). Inadequate OLRS findings among younger, female, and rural respondents. Factors affecting the success of students on the OLRS were age, sex, family socioeconomic status, and where they lived in the neighborhood. The inferences drawn from the study's findings would serve as an excellent benchmark to improve the delivery of elearning processes.
\end{abstract}

Keywords: Economics of education; COVID 19; HEls; Online Learning Readiness; E-learning.

JEL Classification: A20, A29, 120

Recibido: 15 de Junio de 2021

Aceptado: 27 de Septiembre de 2021 


\section{Introduction}

In the world's developing nations, there has been shown to be a correlation between COVID-19 and unstable economies and educational systems. Geographic heterogeneity increases the variability of countries with more deficient socioeconomic development, which has a greater impact on how such countries do when it comes to health (Bhutta et al., 2020, Chang et al., 2021, Hawley et al., 2021). Among the less economically developed nations, Asia has the world's highest concentration of COVID 19. Relying on existing data, it seems that low cumulative yearly income regions have an elevated incidence of COVID-19 infection and high case fatality rates. An apparent effect on the economy and education has been seen due to the present condition of the southeast Asian governments and the ongoing epidemic (Azlan et al., 2020, Baber, 2021, Bhargava et al., 2021, Rajhans et al., 2020, Yekefallah et al., 2021).

Student success levels were reduced because of the closures of all of the schools across the world in the first few months of 2020, and it will be almost impossible to make up for lost ground even if schools quickly return to their former levels of performance. A lot of the students who were touched by this disaster will suffer from financial difficulties for years to come, and each nation will be affected as well. If these consequences are to be avoided, these symptoms must be resolved promptly. In order for a school to safely resume its program, it's essential to focus on logistical and mechanical factors during the time between its closing and reopening. Once current economic losses have been remedied, attention must be paid to the long-term repercussions on the economy.

A critical factor in any country's economic development goals is investing in the country's human resources. People with greater skill levels contribute more to their respective economies and can adapt to technological change. Fertile ground for the rapid growth of economies exists in nations with larger populations of highly educated individuals. Several countries face the immediate risk of short-term student difficulties resulting in long-term damage to the global economy.

As it became clear by the middle of 2020 that COVID-19 was a significant health issue, the whole globe closed its schools and ordered children home. Many nations have started experimenting with different ways to restart their schools beyond this point. Even while the long-term effects have not received the same attention, they are nonetheless quite significant. Furthermore, it has focused on short-term issues in the discussion on policy. A number of strategies were implemented to stop the virus from spreading. Short-term effects on unemployment and delivering short-term welfare benefits have often overshadowed the long-term implications of business closings. Instead of investigating the long-term implications of the virus-induced school closures, we need to focus on solving the immediate and obvious issues created by the present and suspected pandemic. It is clear that the closures of $\mathrm{K}$ 12 schools beginning in the autumn of 2020 will significantly affect students whose education has been affected by these closures. Also, some of the techniques of reopening will worsen these losses. Students and their respective nations are all going to face economic problems that result from these losses.

E-learning, such as electronic learning, has been encouraged in other universities so that class schedules may be prolonged in the case of professors' duties being interrupted (Bhat et al., 2020, Change et al., 2021, Çınar et al., 2021, Pandita et al., 2021, Rafique et al., 2021, Teo et al., 2020). Many colleges and universities have begun utilizing this method as a way to protect the students. At the moment, electronic learning is reserved for those who can afford it. A group of academics believes that the current crop of students doesn't have the aptitude to thrive in an online learning environment, putting pressure on educators to provide more e-learning options (Sharin, 2021, Islam, 2020, Wong et al., 2021). While students who perform well in traditional settings may have difficulty using what they have learned in blended learning environments, many learners may find it challenging in any context, even conventional ones.

Additionally, a second site outside a conventional classroom is used to provide instructional content in the form of an e-learning application via e-learning, which is done through the use of an e-learning application (Abdel-Wahab et al., 2020, Cidral et al., 2020, El Rizaq, \& Sarmini, 2021, Qazi et al., 2020, 
Saha, Dutta, A., \& Sifat, 2021). Students must have technical knowledge and abilities in order to get the greatest value from this kind of learning. Students must know how to utilize new technologies, be self-directed learners, and be ready to learn how to adapt to e-learning to qualify for this award. Prior to the adoption of e-learning, the university system had to evaluate whether or not its students were prepared for e-learning.

Researches assessing online education and Asian students' requirements remain limited to this day. While gender, age, ethnicity, and background factors cannot be properly addressed in the present study, many Asian student population variables (such as gender, age, ethnicity, and background) cannot be appropriately considered. The study's goal was to understand if university students in Asia from the COVID-19 period are ready for e-learning and whether demographic factors are connected to that readiness.

\section{Methodology}

\subsection{Research Design}

This study used a quantitative research strategy that utilized an online survey methodology. The individuals that participated in this study were Southeast Asian university students. Due to ethical considerations, no information was provided about educational institutions. A total of 3,500 online questionnaires were sent through email and Facebook Messenger in March and April of 2021. You may answer the questionnaire anonymously. By distributing surveys to 1000 students in several undergraduate programs, who had given a sampling of usable responses, a satisfactory overall response rate was reached.

\subsection{Instrumentation}

The 27-item questionnaire, which includes gathering demographic information (age, sex, family income class, residence area, kind of school), was used to collect responses from the sample population. Watkins and colleagues updated the OLRS questionnaire, and preparedness for e-learning was measured by its findings. There are six subscales in this survey. The ability to get access to technological resources, internet skills, motivation, and participation in online audio/video (5 items, e.g., Regular contact with the instructor is important to my success in online coursework). The shift to a dichotomous scale resulted in the previously used five-point scale being converted into a dichotomous scale (yes/no). E-learning means they believe they are ready. To see who was really the greatest, individuals' scores were distributed into two groups: the best and the worst. People with test scores between 13 and under are low, whereas those with test scores between 13 and 17 are high. Cronbach alpha overall was 0.87 ; this scale was changed.

\subsection{Data Analysis}

For providing the ratings' descriptive analysis, frequency and percentages were utilized. Chi-square tests were performed to examine the differences between OLRS high and low-prepared respondents. The chances of students' readiness were estimated using each demographic profile in univariate logistic regression. The findings are significant when a p-value less than 0.05 is used.

\section{Results and Discussion}

Table 1 indicates that most respondents were below the age of 22, female, belonged to the lowermiddle class, and attended a public higher educational institution. Similarly, the number of responders from urban and rural locations is almost equal. For all demographic factors, we observed significant differences between respondents who achieved high and low preparedness ratings in OLRS. Younger (below 22 years), female, and in the low-income class, rural region, and public higher education institution were the characteristics of respondents with poor preparedness scores in online learning 
Joel Alanya-Beltran, Zaituna Khamidullina, Mohammad Yousef Alsaraireh, Russell De Souza, Vahdet Tarakci, Jeidy Panduro-Ramirez, Nguyen Tan Hung, Supat Chupradit, Myla M. Arcinas, Hoyan Hang Fung, Carole

readiness and access. Conversely, preparedness scores were found among older respondents, highincome males, private-schooled individuals, and those living in flourishing metropolitan communities.

Table 1 Assessment on the Readiness of the 1200 Sampled Students

\begin{tabular}{|l|c|c|c|}
\hline \multicolumn{1}{|c|}{ Demographic Variables } & $\begin{array}{c}\text { High } \\
\text { readiness } \\
(\%)\end{array}$ & $\begin{array}{c}\text { Low } \\
\text { enthusiasm } \\
(\%)\end{array}$ & p-value \\
\hline Age, years & & & \\
\hline$>22$ & 22.3 & 77 & $<0.001^{*}$ \\
\hline$\leq 22$ & 54.9 & 45.9 & \\
\hline Sex & & & \\
\hline Male & 43.4 & 57.34 & $<0.001$ \\
\hline Female & 30.45 & 70.02 & \\
\hline Family Income Class & & & \\
\hline Low & 1.34 & 98.56 & $<0.001$ \\
\hline Lower Middle & 32.65 & 67.48 & \\
\hline Middle & 47.56 & 52.45 & \\
\hline Upper Middle & 79.45 & 21.45 & \\
\hline High & 98.43 & 2.34 & \\
\hline Living Area & & & \\
\hline Urban & 57.32 & 43.45 & $<0.001$ \\
\hline Rural & 12.65 & 87.56 & \\
\hline Type of School & & & \\
\hline Public & 55.43 & 44.9 & 0.027 \\
\hline Private & 30.76 & 70.43 & \\
\hline
\end{tabular}

A univariate logistic regression analysis was done to connect each demographic feature with the preparedness likelihood (Table 2). Among younger and female respondents, the possibility of scoring poorly in OLRS was greater. Many respondents lived in rural regions and scored poorly on the OLRS as respondents lived in suburban or urban areas. Choosing the kind of school does not affect a student's preparedness.

Table 2 Result of the Univariate logistic regression models with low readiness probability

\begin{tabular}{|c|c|}
\hline Variables & P- value \\
\hline Age & $.0001^{\star *}$ \\
\hline Sex & $.0034^{*}$ \\
\hline Family Income Class & $0.001^{* *}$ \\
\hline Living Area & $.0043^{*}$ \\
\hline Type of School & $0.76 \mathrm{~ns}$ \\
\hline
\end{tabular}

${ }^{*}=$ significant at 0.05 level; $\mathrm{ns}=$ not significant at 0.05 level

Note: all other variables are not significant

Previously stated data imply that the family's total school-related budget may be redistributed to satisfy other needs. Study results indicate that college students' preparedness for e-learning in the case of a COVID-19 pandemic was limited (Ali et al., 2021, Cho \& Hong, 2021, Elumalai et al., 2021). There are several reasons these issues are so prevalent, including the absence of a computer and/or Internet connection, as well as software deficiencies (Gunawardhana, 2020, Khawar et al., 2021, Kuchenbuch et al., 2020). Their team is confident they lack the necessary technical abilities to maintain a directory of files and files and subdirectories on the internet (e.g., using search engines, entering passwords). Previous researches claim that millennials' digital capabilities are weak (Obeta et al., 2020, Pal \& Vanijja, 2020). More than $60 \%$ of millennials have poor digital abilities while focusing on their studies while playing online games is very popular. This may allow for better learning methods to be 
created, which may help developers design better learning approaches that could help more people use better digital gaming abilities before making the complete transition to e-learning. In like manner, many low-income and rural students did not think they were ready for college, but in reality, this was the case for the majority of the group. The assumption here is that learners in certain categories may not be ready for e-learning in this result. Equipment such as computers and speakers may be in short supply in certain areas, as well as access to the Internet, which may impact readiness ratings. Young people are really less equipped than older people to handle the unforeseen. It's notable that a significant proportion of the recent graduates from the secondary level had recently made a big career shift. It's possible that since they were the first to go through an additional two years of secondary school, they will find it difficult to embrace another educational system. Many distinct factors influence the readiness assessments of the respondents. That is a problem since resistance to potential changes in the education system could be seen in the online survey participants, who reported feeling more psychological pain in the country where the study was performed. According to several of the instructors, the semester should conclude, and they want to provide more students chances to be promoted. Students who take mass-marketing methods (essentially a universal pass that bypasses their present academic standing for the next academic year regardless of their performance in the second semester) would, in theory, help even those who underperform academically. Social or administrative promotion is also known as social or administrative education and is often used to refer to students who test below the norm on academic achievement assessments. It's a design that empowers students who have previously failed their class to continue their education despite past failures. Many students responded to this outreach, showing that online learning is likely to remain a niche practice in academia.

\section{Conclusion}

While this study has many limitations, the findings remain consistent. Because it is a cross-sectional study, the results of this research can only be applied to one time period. It may be possible to do large-scale longitudinal studies to examine changes in preparation levels over time. More important factors that may unwind the learners' preparation may be evaluated via a qualitative study. Survey participants were both emotionally and mentally disturbed during the public health emergency. As a result, the prejudices of participants had a significant impact on the conclusions of the study.

As a consequence of this skewed view of their readiness for e-learning, their views of it are flawed. This is the first empirical study on Asian' readiness for e-learning that has been conducted to date. School authorities may first focus on providing students with digital skills, and then they may provide their students' digital training to help them improve their digital competence.

\subsection{Implications to Economics of Education}

Culminating in an exponential rise in research in recent years, education economics deals with everexpanding economic theories, models, and quantitative methods. Various theories and models have been developed and used by economists to solve a variety of substantive issues throughout education sectors, from formal to informal, and education levels, from early childhood education to higher education. Economists in education are investigating some of the most significant problems in education that they have identified so far, such as charter schools and voucher systems, teacher accountability, and the widening achievement disparities. Because the topics at the forefront of academic research in education change rapidly, the resources included in this directory respond to current education policy debates, emphasizing the topics that are most current, relevant, and applicable to educational issues both at home and abroad. As to the economic implications of the study, before creating an e-learning shift in low-income and rural areas, you must take care of the financial, operational, and Internet connection issues. Equal and inclusive education requires more strategic planning and mechanisms for quality control that are not incompatible with learning quality. The results of the present study may provide a clear picture for the governments among select South 
East Asian countries on the following: (1) provision on higher funding opportunities for the technological literacy of students; (2) higher monetary support for students who belonged to poor and rural areas; (3) support on the technological literacy of teachers; (4) allocation of funds for the IT infrastructure for better access of students in e-learning.

\section{References}

1. Abdel-Wahab, M., Rosenblatt, E., Prajogi, B., Zubizarretta, E., \& Mikhail, M. (2020). Opportunities in telemedicine, lessons learned after COVID-19, and the way into the future. International Journal of Radiation Oncology, Biology, Physics, 108(2), 438-443.

2. Ali, S., Gulliver, S. R., Uppal, M. A., \& Basir, M. (2021). Research investigating individual device preference and e-Learning quality perception: can a one-solution-fits-all e-learning solution work?. Heliyon, e07343.

3. Azlan, C. A., Wong, J. H. D., Tan, L. K., Huri, M. S. N. A., Ung, N. M., Plath, V., ... \& Ng, K. H. (2020). Teaching and learning of postgraduate medical physics using Internet-based e-learning during the COVID-19 pandemic-A case study from Malaysia. Physica Medica, 80, 10-16.

4. Baber, H. (2021). Modelling the acceptance of e-learning during the pandemic of COVID-19-A study of South Korea. The International Journal of Management Education, 19(2), 100503.

5. Bhargava, S., Negbenebor, N., Sadoughifar, R., Ahmad, S., \& Kroumpouzos, G. (2021). Virtual conferences and e-learning in dermatology during COVID-19 pandemic: results of a web-based, global survey. Clinics in Dermatology.

6. Bhat, R., Singh, V. K., Naik, N., Kamath, C. R., Mulimani, P., \& Kulkarni, N. (2020). COVID 2019 outbreak: The disappointment in Indian teachers. Asian Journal of Psychiatry, 50, 102047.

7. Bhutta, Z. A., Basnyat, B., Saha, S., \& Laxminarayan, R. (2020). Covid-19 risks and response in South Asia.

8. Cidral, W., Aparicio, M., \& Oliveira, T. (2020). Students' long-term orientation role in e-learning success: A Brazilian study. Heliyon, 6(12), e05735.

9. Çınar, M., Ekici, M., \& Demir, Ö. (2021). A snapshot of the readiness for e-learning among in-service teachers prior to the pandemic-related transition to e-learning in Turkey. Teaching and Teacher Education, 107, 103478.

10.Chang, T. Y., Hsu, M. L., Kwon, J. S., Kusdhany, M. L. S., \& Hong, G. (2021). Effect of online learning for dental education in Asia during the pandemic of COVID-19. Journal of Dental Sciences.

11.Cho, M. J., \& Hong, J. P. (2021). The emergence of virtual education during the COVID-19 pandemic: The past, present, and future of the plastic surgery education. Journal of Plastic, Reconstructive \& Aesthetic Surgery, 74(6), 1413-1421.

12.El Rizaq, A. D. B., \& Sarmini, S. (2021). Secondary School Teachers and Learners Perspective for Future of Education Post COVID-19 Pandemic. Tadris: Jurnal Keguruan dan Ilmu Tarbiyah, 6(1), 171182.

13.Elumalai, K. V., Sankar, J. P., Kalaichelvi, R., John, J. A., Menon, N., Alqahtani, M. S. M., \& Abumelha, M. A. (2021). Factors Affecting the Quality of E-Learning During the COVID-19 Pandemic from the Perspective of Higher Education Students. COVID-19 and Education: Learning and Teaching in a Pandemic-Constrained Environment, 189.

14.Gunawardhana, L. K. (2020). Review of E-Learning as a Platform for Distance Learning in Sri Lanka. Education Quarterly Reviews, 3(2).

15. Hawley, S. R., Thrivikraman, J. K., Noveck, N., Romain, T. S., Ludy, M. J., Barnhart, L., ... \& Tucker, R. M. (2021). Concerns of college students during the COVID-19 pandemic: Thematic perspectives from the United States, Asia, and Europe. Journal of Applied Learning and Teaching, 4(1).

16.Islam, S. D. U., Bodrud-Doza, M., Khan, R. M., Haque, M. A., \& Mamun, M. A. (2020). Exploring COVID-19 stress and its factors in Bangladesh: a perception-based study. Heliyon, 6(7), e04399.

17.Khawar, M. B., Abbasi, M. H., Hussain, S., Riaz, M., Rafiq, M., Mehmood, R., ... \& Farooq, A. (2021). Psychological impacts of COVID-19 and satisfaction from online classes: disturbance in daily routine 
and prevalence of depression, stress, and anxiety among students of Pakistan. Heliyon, 7(5), e07030.

18.Kuchenbuch, M., d'Onofrio, G., Wirrell, E., Jiang, Y., Dupont, S., Grinspan, Z. M., ... \& Nabbout, R. (2020). An accelerated shift in the use of remote systems in epilepsy due to the COVID-19 pandemic. Epilepsy \& Behavior, 112, 107376.

19. Obeta, M. U., Etukudoh, N. S., \& Ejinaka, R. O. (2020). A Case of Online Teaching and Learning during COVID-19 in Medical Laboratory Science Education and Training in Federal School of Medical Laboratory Science, Jos. Southeast Asian Journal of Medical Education, 14(2), 108.

20.Pal, D., \& Vanijja, V. (2020). Perceived usability evaluation of Microsoft Teams as an online learning platform during COVID-19 using system usability scale and technology acceptance model in India. Children and youth services review, 119, 105535.

21.Pandita, S., Mishra, H. G., \& Chib, S. (2021). Psychological impact of covid-19 crises on students through the lens of Stimulus-Organism-Response (SOR) model. Children and Youth Services Review, 120, 105783.

22.Qazi, A., Naseer, K., Qazi, J., Salman, H., Naseem, U., Yang, S., ... \& Gumaei, A. (2020). Conventional to online education during COVID-19 pandemic: Do develop and underdeveloped nations cope alike. Children and Youth Services Review, 119, 105582.

23. Rafique, G. M., Mahmood, K., Warraich, N. F., \& Rehman, S. U. (2021). Readiness for Online Learning during COVID-19 pandemic: A survey of Pakistani LIS students. The Journal of Academic Librarianship, 47(3), 102346.

24.Rajhans, V., Memon, U., Patil, V., \& Goyal, A. (2020). Impact of COVID-19 on academic activities and way forward in Indian Optometry. Journal of Optometry, 13(4), 216-226.

25.Saha, A., Dutta, A., \& Sifat, R. I. (2021). The mental impact of digital divide due to COVID-19 pandemic induced emergency online learning at undergraduate level: Evidence from undergraduate students from Dhaka City. Journal of Affective Disorders, 294, 170-179.

26.Sharin, A. N. (2021). E-learning During Covid-19 A Review of Literature. Jurnal Pengajian Media Malaysia, 23(1).

27.Teo, L. W., Pang, T., Ong, Y. J., \& Lai, C. (2020). Coping with COVID-19: perspectives of student radiographers. Journal of medical imaging and radiation sciences, 51(3), 358.

28.Wong, C. W., Tsai, A., Jonas, J. B., Ohno-Matsui, K., Chen, J., Ang, M., \& Ting, D. S. W. (2021). Digital screen time during the COVID-19 pandemic: risk for a further myopia boom?. American journal of ophthalmology, 223, 333-337.

29.Yekefallah, L., Namdar, P., Panahi, R., \& Dehghankar, L. (2021). Factors related to students' satisfaction with holding e-learning during the Covid-19 pandemic based on the dimensions of elearning. Heliyon, e07628. 